\title{
Seroprevalence and lethality by SARS-CoV-2 in indigenous populations of Latin America and the Caribbean: A systematic review
}

\author{
Akram Hernández-Vásquez ${ }^{1}$, Fabian Chavez-Ecos ${ }^{2}$, Antonio Barrenechea-Pulache ${ }^{\text {Corresp., }}{ }^{3}$, Daniel Comandé ${ }^{4}$, Guido \\ Bendezu-Quispe ${ }^{5}$ \\ ${ }^{1}$ Centro de Excelencia en Investigaciones Económicas y Sociales en Salud, Vicerrectorado de Investigación, Universidad San Ignacio de Loyola, Lima, Peru \\ 2 Sociedad Científica de Estudiantes de Medicina de Ica, Universidad Nacional "San Luis Gonzaga", Ica, Peru \\ 3 Universidad Cientifica del Sur, Lima, Peru \\ 4 Institute for Clinical Effectiveness and Health Policy (IECS), Buenos Aires, Argentina \\ 5 Centro de Investigación Epidemiológica en Salud Global, Universidad Privada Norbert Wiener, Lima, Peru \\ Corresponding Author: Antonio Barrenechea-Pulache \\ Email address: abarrenechea@cientifica.edu.pe
}

Background: Latin America and the Caribbean (LAC) has presented some of the highest numbers of cases and deaths due to COVID-19 in the world. Even though indigenous communities represent $8 \%$ of the total population in this region, the impact of COVID-19 on this historically vulnerable population has only been briefly explored. Thus, this study aimed to estimate the seroprevalence and lethality attributable to SARS-CoV- 2 in the indigenous population of LAC. Methods: A systematic review was conducted utilizing multiple databases (registry PROSPERO: CRD42020207862). Studies published in English,

Spanish or Portuguese were selected between December 1st, 2019, and April 14 ${ }^{\text {th }}, 2021$. The evaluation of the quality of the study was carried out utilizing the Quality Assessment Tool for Observational Cohort and Cross-Sectional Studies. A qualitative synthesis of the data analyzed was conducted following the MOOSE and PRISMA declarations. Results: Fifteen studies met the inclusion criteria. Eleven studies were carried out in a Brazilian population, three in a Mexican population, and one in a Colombian population. Four studies reported data about the seroprevalence of SARS-CoV-2 in indigenous populations of Brazil (range: 4.2\%-81.65\%). Twelve studies reported lethality in indigenous people (eight in Brazil, three in Mexico, and one in Colombia). In Brazil, a lethality of $53.30 \%$ was described in a hospital setting and between $1.83 \%$ and $4.03 \%$ in community studies. In Mexico, the lethality of COVID-19 ranged between $16.5 \%$ and $19.9 \%$. Meanwhile, in Colombia, a lethality of $3.41 \%$ was reported. Most studies were deemed to be of good quality.

Conclusions: Despite COVID-19 affecting indigenous populations of LAC, there is limited evidence of the seroprevalence and lethality of the infection by SARS-CoV-2 in this 
population. Future investigations should ensure standardized methods that allow comparability among studies and ensure the precision of the results obtained. 
1 Seroprevalence and lethality by SARS-CoV-2 in indigenous populations of Latin America and the Caribbean: A systematic review

3

4 Akram Hernández-Vásquez ${ }^{1}$, Fabian Chavez-Ecos ${ }^{2}$, Antonio Barrenechea-Pulache ${ }^{3}$, Daniel 5 Comandé $^{4}$, Guido Bendezu-Quispe ${ }^{5}$

6

$7{ }^{1}$ Centro de Excelencia en Investigaciones Económicas y Sociales en Salud, Vicerrectorado de 8 Investigación, Universidad San Ignacio de Loyola, Lima, Peru.

$9{ }^{2}$ Sociedad Científica de Estudiantes de Medicina de Ica, Universidad Nacional San Luis Gonzaga, 10 Ica, Peru.

$11{ }^{3}$ Universidad Científica del Sur, Lima, Peru.

$12{ }^{4}$ Institute for Clinical Effectiveness and Health Policy (IECS), Buenos Aires, Argentina.

$13{ }^{5}$ Universidad Privada Norbert Wiener, Centro de Investigación Epidemiológica en Salud Global, 14 Lima, Peru.

16 Corresponding Author:

17 Antonio Barrenechea-Pulache ${ }^{3}$

18 Email address: abarrenechea@cientifica.edu.pe 


\section{ABSTRACT}

20 Background: Latin America and the Caribbean (LAC) has presented some of the highest

21 numbers of cases and deaths due to COVID-19 in the world. Even though indigenous

22 communities represent $8 \%$ of the total population in this region, the impact of COVID-19 on this

23 historically vulnerable population has only been briefly explored. Thus, this study aimed to

24 estimate the seroprevalence and lethality attributable to SARS-CoV-2 in the indigenous

25 population of LAC.

26 Methods: A systematic review was conducted utilizing multiple databases (registry

27 PROSPERO: CRD42020207862). Studies published in English, Spanish or Portuguese were

28 selected between December 1st, 2019, and April 14 ${ }^{\text {th }}, 2021$. The evaluation of the quality of the

29 study was carried out utilizing the Quality Assessment Tool for Observational Cohort and Cross-

30 Sectional Studies. A qualitative synthesis of the data analyzed was conducted following the

31 MOOSE and PRISMA declarations.

32 Results: Fifteen studies met the inclusion criteria. Eleven studies were carried out in a Brazilian

33 population, three in a Mexican population, and one in a Colombian population. Four studies

34 reported data about the seroprevalence of SARS-CoV-2 in indigenous populations of Brazil

35 (range: 4.2\%-81.65\%). Twelve studies reported lethality in indigenous people (eight in Brazil,

36 three in Mexico, and one in Colombia). In Brazil, a lethality of 53.30\% was described in a

37 hospital setting and between $1.83 \%$ and $4.03 \%$ in community studies. In Mexico, the lethality of

38 COVID-19 ranged between 16.5\% and 19.9\%. Meanwhile, in Colombia, a lethality of 3.41\%

39 was reported. Most studies were deemed to be of good quality.

40 Conclusions: Despite COVID-19 affecting indigenous populations of LAC, there is limited

41 evidence of the seroprevalence and lethality of the infection by SARS-CoV-2 in this population.

42 Future investigations should ensure standardized methods that allow comparability among

43 studies and ensure the precision of the results obtained. 


\section{INTRODUCTION}

45

46

47

48

49

50

51

52

53

54

55

56

57

58

59

60

61

62

63

64

65

66

67

68

69

70

71

72

73

74

Since the detection of the first case of SARS-CoV-2 in Wuhan, China, in 2019, the propagation of this virus has increased until being declared a pandemic on the 11th of March 2020 (1). The most common mode of transmission is through respiratory droplets and prognosis of the patient depends on several factors including age, severity of disease presentation, comorbidities and response to treatment (2). One of the groups most vulnerable to SARS-CoV-2 is the indigenous population due to the presence of social determinants at an individual, community, and societal level that condition lower health quality. These include higher levels of poverty, malnutrition, lower levels of education, poor access to essential sanitation services, difficulties accessing health care services due to geographical and cultural barriers, and low availability of adequately equipped health care establishments (3-5). Likewise, immunological factors and chronic diseases have been reported to increase the susceptibility to infectious disease outbreaks in this group of people (6). A negative effect on the health status of indigenous people has been described in recent decades due to these diseases with lethality up to six times that found in the general population $(3,7,8)$.

0

1 Latin America and the Caribbean (LAC) has presented some of the highest numbers of cases and deaths due to COVID-19 in the world (9). The first regional case of SARS-CoV-2 infection was reported in February 2020 in Brazil, while the first death due to COVID-19 was reported in Argentina in March (10). In LAC, there are over 800 indigenous communities, and together they account for approximately 60 million people, representing $8 \%$ of the total population. Thus, LAC presents the highest proportion of indigenous people compared to other inhabitants (11). Indigenous populations have conditions that make them vulnerable to the COVID-19 pandemic. These conditions include high levels of poverty, which affect $43 \%$ of indigenous households, an average salary $31 \%$ lower than that of other workers, lower levels of education with reports indicating that only $20 \%$ of indigenous populations obtain conventional education and lower access to health care $(5,11)$. It was to be expected that these historical inequalities would increase during the COVID-19 pandemic, causing indigenous people to be left behind when distributing scarce resources, such as diagnostic tests, personal protective equipment, mechanical ventilators, and medication necessary for the treatment of critically ill patients $(5,8)$, being a scenario that 
75 increases the risk of severe disease and death in this group. Thus, tending to the needs of

76 indigenous populations in LAC continues to be a challenge and has been made even greater due 77 to the current events of the pandemic.

78

79 To date, an ever-growing number of COVID-19 cases has been reported in all LAC countries

80 (9), including cases among indigenous people in this region (12). Regardless, the presence and 81 the impact of the COVID-19 pandemic on mortality in indigenous populations of LAC have 82 seldom been studied. Thus, we carried out a systematic review to estimate the seroprevalence 83 and lethality attributable to COVID-19 in indigenous populations of (LAC). This information 84 could serve as evidence to generate strategies oriented towards better allocation of health 85 resources in this population.

86

\section{METHODS}

88

This systematic review was registered in the PROSPERO database (registration code:

CRD42020207862) and reported using the guidelines of the Meta-analysis of Observational

Studies in Epidemiology (MOOSE) (13) and Preferred Reporting Items for Systematic Reviews and Meta-Analyses (PRISMA) statements (14).

\section{Study inclusion and exclusion criteria}

We used the CoCoPop approach (Condition, Context, and Population) to establish inclusion and exclusion criteria in studies describing seroprevalence and lethality due to SARS-CoV-2 (15). All observational s tudies published in English, Spanish or Portuguese between December 1st, 2019, and April 14th, 2021, that estimated the prevalence and lethality of COVID-19 among indigenous populations of LAC regardless of age, were eligible for inclusion. All observational study designs that estimate prevalence and lethality in this population were selected for review. This time frame was chosen because the first group of COVID-19 cases in China was reported in December 2019 (16). Publications such as systematic reviews, review articles, congressional acts, letters, commentaries, and editorials were excluded. Gray literature was not included (the 
105 search was restricted to publications evaluated by an editorial committee to maintain rigor and 106 ensure the quality of the selected studies).

107

108

\section{Data sources}

109

110 Searches were conducted in the following databases: PubMed, Embase (Excerpta Medica Database), CINAHL (Cumulative Index to Nursing and Allied Health Literature), Web of Science, Scopus, Google Scholar, and the regional database LILACS (Literatura Latinoamericana y del Caribe en Ciencias de la Salud) to identify studies that were of interest.

114 While utilizing Google Scholar, the number of results reviewed was limited to the first 10 pages

115 following the recommendations on using this database to conduct a systematic review $(17,18)$. 116

117 Study Outcomes: Lethality and seroprevalence

119 For our review, lethality was defined as the proportion of indigenous patients diagnosed or suspected of having COVID-19 who died during the study period as a result of said disease; this was often reported as a percentage among the findings of the cited article. Likewise, seroprevalence was defined as the proportion of individuals tested for and found to possess COVID-19 antibodies; this was also often reported in the cited article.

\section{Search strategies and screening}

The research team developed the search strategies with the guidance of a librarian with experience in medical investigation (DC). These strategies were reviewed and approved by all researchers. After approval of the search strategies, one author (DC) executed the search, compiled the results and eliminated duplicates. Date and publication status were not considered as restrictions. The search was limited to studies published in English, Spanish or Portuguese since these are the official languages of LAC countries and are widely utilized to inform studies in this region. Furthermore, searches were conducted using the reference lists of all relevant articles. The search strategy is described in Appendix S1. 
136 The search results were exported to EndNote X9 (Thompson and Reuters, Philadelphia, USA) to 137 eliminate duplicate publications. Next, titles and/or abstracts of the retrieved publications were 138 screened independently by two review authors (AHV and ABP) to identify studies that 139 potentially met the inclusion criteria of this review using the web application Rayyan 140 (https://rayyan.qcri.org/). Each selected publication was classified into the following categories: 141 excluded, maybe, and included. In the case of maybe or a conflict about the inclusion of any 142 publication, the reviewers discussed and achieved consensus regarding inclusion or exclusion of 143 that publication.

144

145

146

147

148

149

150

151

152

153

154

155

156

157

158

159

160

161

162

163

164

165

166

All studies included by titles and abstracts entered the full-text evaluation phase. These studies were evaluated independently by the same members of the review team. In the case of conflict between reviewers, this was discussed, and consensus was achieved regarding the inclusion or exclusion of that publication.

\section{Data extraction}

Two review authors (AHV and ABP) extracted the relevant data independently using a standardized data extraction sheet. In the case of disagreement, this was resolved by a discussion between the two authors. The following data were extracted from each study: date of publication, first author, journal name, type o publication, language, study objectives, period of data collection, country, size and sample characteristics, operational definition of a COVID-19 case, and data on seroprevalence and lethality in COVID-19 patients.

\section{Quality Assessment}

Two reviewers (AHV and ABP) independently evaluated the quality of the studies included. In the case of disagreement, this was resolved by discussion between the two authors. The quality assessment was conducted utilizing the Quality Assessment Tool for Observational Cohort and Cross-Sectional Studies of the National Institutes of Health (19). This tool considers 14 criteria to evaluate the risk of bias in selection, information, measure, and confusion. Each of the studies included was evaluated with these 14 criteria ("Yes" was considered in the case that it complied 
167 with the criteria; "No", in the case that it did not comply with the criteria; "NA", when the 168 criteria did not apply to the study; "ND", when the criteria were not possible to determine; and 169 "NR", when the information regarding the evaluated criteria was not reported). Following the 170 methodology for objective evaluation of the quality employed in previous systematic reviews 171 that have utilized this tool, each criterion assigned "Yes" summed one point to the overall score 172 and criteria evaluated, while no points were added for "No" and "ND" (0 points). The criteria 173 qualified as "NA" did not count towards the percentage of points of the maximum total possible. 174 The quality of a study was evaluated according to the percentage of the maximum score obtained 175 ( $>50 \%$ good, $30-50 \%$ regular, $<30 \%$ bad) $(20,21)$.

176

\section{Data synthesis}

178

We utilized a narrative synthesis focus. Findings were presented in summary tables, following the MOOSE guideline (14). Descriptive tables were constructed with information on the seroprevalence and/or lethality of SARS-CoV-2 in groups of the indigenous population of LAC. Descriptive summaries of the results for indigenous populations, including country, sex, age, comorbidities, and ethnic group, were reported.

\section{Ethics}

Ethics approval was not required for this study because it was based on published studies.

\section{Funding}

This study obtained a grant from the Universidad Privada Norbert Wiener. The funder did not have any role in the study design, data collection, data synthesis, analysis, or preparation of the manuscript.

192

\section{RESULTS}

194

\section{Search results}

We obtained a total of 747 unique results from the search after eliminating duplicates. After 
198 revision by title and abstract, 26 full-text articles were read. Following evaluation, one study was 199 found to be an editorial, and 10 did not provide data on indigenous people, and were, thus, 200 excluded. In the end, 15 studies complied with the inclusion criteria and are reported below 201 (Figure 1).

202

203

\section{Study characteristics}

204

205

All the studies included were published between 2020-2021 and were cross-sectional $(\mathrm{n}=15)$.

206 Eleven of the included studies were conducted in the indigenous population of Brazil (22-32),

207 three were conducted in the indigenous population of Mexico (33-35), and one in Colombia 208 (36). No multicounty studies were included. The studies that reported lethality included sample 209 sizes of the indigenous people infected with COVID-19 which varied from 15 to 41,855 individuals, while those that reported seroprevalence tested samples of indigenous people that ranged from 100 to 2890 individuals. Likewise, most studies were published in English; only one was published in Portuguese (28), and two were also available in Spanish (26,33). Only five of the included studies specified data about the age and sex of the indigenous participants studied

$214(27,28,31,34,35)$. Six of the studies were conducted specifically in the indigenous population, all 215 from Brazil $(24,25,27,28,30,31)$. Three pairs of studies analyzed the same database during a 216 similar time frame; thus, the results of one study may have been included in those of another $217(22,23,26,28,34,35)$ (Table 1).

\section{Results related to the seroprevalence of SARS-CoV-2 infection}

220

Four studies $(22,26,27,31)$ reported data about the seroprevalence of SARS-CoV-2 in indigenous 222 populations in Brazil (Table 1). The two largest studies conducted household surveys of 1219 indigenous people through three surveys and 767 indigenous people in two surveys, respectively. Horta et al. reported a seroprevalence of $5.4 \%$ for the three surveys, while Hallal et al. reported a 225 seroprevalence of $4.2 \%$ (95\% confidence interval [CI] 2.2-7.2) in the first survey and $6.3 \%$ (95\% CI 4.2-9.2) in the second survey, after adjusting for the design and validity of the diagnostic test. The third study conducted surveys in the Xikrin of Bacajá indigenous population (Kayapó) 
229 indigenous individuals, $58 \%$ of whom were $\mathrm{IgG}$ reactive by a rapid test, and $73 \%$ were reactive 230 in an enzyme-linked immunosorbent assay (27). Finally, the fourth study was conducted in 231 various indigenous communities in Amaturá, Amazonas. In this study, a total of 109 individuals 232 with respiratory symptoms were tested using an unspecified rapid test, 89 of whom tested 233 positive with a seroprevalence of $81.65 \%(31)$.

234

\section{Results related to lethality by SARS-CoV-2}

236

237 Twelve studies reported data on the lethality in indigenous populations; eight were from Brazil 238 (23-25, 28-32), three from Mexico (33-35), and one from Colombia (36) (Table 1). Regarding 239 the Brazilian studies, lethality ranged between $0 \%$, in a study that reported zero deaths among 89 240 confirmed COVID-19 cases (28), and 53.3\% in a study that included 15 indigenous people with 241 COVID-19 in a hospital setting, eight of whom died (23). Mendes et al. conducted a cross242 sectional study including the largest sample of COVID-19 cases among indigenous individuals $243(\mathrm{n}=41,855)$, among whom 549 died, reporting a lethality of 1.31\% (30). In Mexico, Ibarra et al. 244 reported that 691 people of a total of 4178 COVID-19 indigenous cases died, obtaining a 245 lethality of $16.5 \%$ (35). Argoty et al. found that 768 out of 4469 infected indigenous people died, 246 reporting a lethality of $17.2 \%$ (34), and Ortiz-Hernández et al. reported lethality of 19.9\% 247 (though this publication did not specify the exact number of deaths) (33). Lastly, in the study 248 conducted in Colombia, it was reported that 776 of a total of 22,787 infected indigenous 249 individuals died, with lethality of $3.4 \%$ (36).

250

\section{Study Quality}

252

253

Most studies were qualified as having good quality ( $>50 \%$ of the maximum score utilizing the 254 Quality Assessment Tool for Observational Cohort and Cross-Sectional Studies of the National 255 Institutes of Health). Only three were found to have regular quality (50\%) (Table 2).

256

257

\section{DISCUSSION}

258

259

This systematic review aimed to summarize the evidence available on the seroprevalence and 
260 lethality of infection by SARS-CoV-2 in the indigenous populations of LAC. Only a few non261 representative studies measuring outcomes of COVID-19 in the indigenous people of LAC 262 countries were available. In general, only three Latin American countries (Brazil, Mexico, and 263 Colombia) have studied and reported data on seroprevalence and lethality in indigenous 264 populations, including studies at community (12/15) and hospital levels (3/15). Likewise, only 26512 studies were designed to evaluate the lethality of COVID-19 in the indigenous population 266 (eight in Brazil). In general, the studies found had a cross-sectional design. The seroprevalence 267 of SARS-CoV-2 was only reported in the indigenous population of Brazil, with values between 2684.2 and $81.65 \%$. Regarding lethality, higher values were reported in studies carried out in 269 hospital settings ( $19.9 \%$ to $53.33 \%)$ compared to those conducted in a community setting $(0 \%$ to $27048.74 \%)$.

271

272 Regarding the seroprevalence of indigenous populations, the studies identified only evaluated the 273 Brazilian indigenous population using small sample sizes; the study with the largest sample 274 reported a seroprevalence of 5.4\%. After reviewing the available literature, we found that there is 275 also scarce information regarding the seroprevalence of SARS-CoV-2 in the indigenous 276 populations of other regions of the world. One study in the indigenous population of Alaska 277 reported that the prevalence of SARS-Cov-2 infection reached 1.3\% (37), a value within the 278 range found in studies in the indigenous population of Brazil reported in this review. We 279 emphasize that Brazil is one of the countries with the highest number of cases of COVID-19 in 280 the world ( $3^{\text {rd }}$ place), with approximately 19 million cases by July 2021 (9). Studies presenting 281 results regarding the seroprevalence of SARS-CoV-2 in other LAC countries were not found. 282 However, in countries such as Bolivia (38), Peru (39), Ecuador (40), Venezuela (12), and 283 Colombia (41), cases of COVID-19 have been reported in the indigenous populations. During 284 the COVID-19 pandemic, a deficit of diagnostic tests, lack of masks, and the suspension of 285 health programs in indigenous communities have been described (42), being a situation that 286 could lead to a decline in health care in these communities as well as an underestimation of the 287 prevalence of COVID-19 in indigenous populations. Thus, health care for this historically vulnerable group should be prioritized during times of crisis. Additionally, given that most countries report official information on COVID-19 without disaggregating it according to ethnicity (43), it is necessary to overcome the deficiencies in the data recording process to 
291 evaluate the impact of COVID-19 or other diseases in indigenous communities.

292

293 Regarding lethality, differences were found among the studies evaluating the Brazilian

294 population (23\% and $53.3 \%$ in the hospital setting; $0 \%$ to $48.74 \%$ in the community setting) and 295 the Mexican population (19.9\% in the hospital setting). The difference in the lethality among the 296 297 298 299

300

301

302

303

304

305

306

307

308

309

310

311

312

313

314

315

316

317

318

319

320

321 studies reported and the fact that higher lethality has been reported in hospital settings could be due to indigenous patients with more severe forms of COVID-19 being concentrated in the hospital setting, raising the lethality due to COVID-19 among the patients that received medical care in a hospital setting. Until July 13th, 2021, Brazil $(534,233)$ and Mexico $(235,058)$ reported two of the highest numbers of deaths due to COVID-19 worldwide (second and fourth place, respectively) (9). Regarding the number of COVID-19 cases in these countries, the lethality due to COVID-19 in the general population in Mexico is the highest in the world with 9.06\%, being $2.80 \%$ in Brazil (9). Similar to the outcomes of seroprevalence of SARS-CoV-2, we found no study on lethality due to COVID-19 in other countries of LAC. Nevertheless, deaths due to COVID-19 in the indigenous population of other Latin American countries such as Bolivia, Peru, Colombia, and Ecuador show hundreds of deaths due to COVID-19 in indigenous communities $(38,40,41,44)$. The trust for the development of indigenous communities in LAC stated that by December 2020 over 73,000 cases of COVID-19 and 21,000 deaths had been reported among indigenous communities of the amazon region. Many of these communities were already vulnerable due to poor levels of sanitation and dependence on income from daily manual labor, and many were left to fend for themselves due to being geographically isolated opting to turn towards traditional medicine as a means of combatting illness (45). Considering the potential sub-registration of cases and deaths due to COVID-19 in these countries, the predisposition of indigenous populations, and limitations in the availability of diagnostic tests, COVID-19 may be an important cause of mortality in indigenous people.

17 To date, international organizations such as the Pan American Health Organization have required governments of LAC countries to implement measures to slow the spread of COVID-19 in indigenous communities, including increasing the number of health workers and medical supplies, as well as providing diagnostic tests for COVID-19 and vaccines and treatments for this disease when available (46). The need to adopt emergency measures to protect this population 
322 was demonstrated in Brazil, where a supreme court (August 2020) exposed the Brazilian

323 government's failure to protect the indigenous population from the impact of COVID-19 after an

324 indigenous leader had died from this disease (47). It should be noted that in countries with

325 indigenous communities in the Amazon area, including Brazil, Colombia, and Peru, the presence

326 of illegal extractive activities generates a great environmental and direct impact on the health of

327 these communities by exploiting the resources used for their subsistence and requiring them to

328 move from their territory, likely facilitating the introduction and spread of COVID-19 (48-50).

329 Regarding the previous issue, the Brazilian court also pointed out the need to expel illegal gold

330 miners from protected areas (47). Therefore, it is urgent that governments take measures to

331 control activities that could introduce COVID-19 and cause environmental impacts that affect the

332 health of indigenous communities.

333

334 Indigenous communities have taken an active role in their protection against COVID-19. In

335 LAC, for example, it is described that indigenous communities in Brazil, such as Paiter Suruí and

336 Parque Ingidena do Xingu established voluntary quarantines in March 2020 (4). Furthermore, in

337 Peru, it has been described that the majority of the communities of the rural districts Nauta,

338 Parinari, and Sequena prohibited the entry of people not belonging to the community. However,

339 half of these communities did allow residents to travel to the cities for commercial and social

340 reasons, and the prohibition of social events was only abided by a third of the communities since

341 the control measure, decreed by the Peruvian government, competes with their daily routine (42).

342 Although it is described that the measures taken by governments to control the spread of

343 COVID-19 towards indigenous communities have been deficient (43), it should be emphasized

344 that mistrust in authority and disbelief in the existence and severity of the pandemic likely

345 influenced outcomes $(43,51)$. Therefore, effective, culturally appropriate communication

346 strategies with the communities should be established to transmit accurate information about

347 COVID-19 (51). These strategies should also include the participation of community

348 representatives $(11,43)$. Authorities could also establish differentiated lockdowns according to

349 the number of individuals affected by COVID-19 in the indigenous communities to reduce the

350 impact in the activities of these populations.

351

352 This review has some limitations. Although we sought to be comprehensive in terms of 
353 information sources, including a regional bibliographic database such as LILACS as well as a 354 search engine such as Google Scholar and including documents in the main languages of the 355 LAC countries, there may be publications in the gray literature on the study subject that would 356 not have been collected as they were not indexed in the information sources used. Likewise, we 357 found few studies from few LAC countries examining COVID-19 in the indigenous population. 358 Also, there were limitations regarding the information provided in the studies evaluated; for 359 example, in some cases, no information on the recruitment criteria of the participants or type of

360 361 362

363 364 365 366 368 371 372 369 and lethality of SARS-CoV-2 in the indigenous population of LAC. The few studies identified 370 described the presence of COVID-19 in indigenous people of Brazil, Mexico, and Colombia. 373 order not to leave anyone behind, future investigations with a prospective design should aim 374 towards the use of standardized methods that allow comparability among the studies of 375 seroprevalence and lethality of SARS-CoV-2 in this population, this data should be made readily 376 available to allow evaluation of the true impact of COVID-19 in indigenous people, who have 377 historically had inequality in access to medical care. test used to detect positive SARS-CoV-2 cases was available. Furthermore, there is variability in the reporting of results, which did not allow a meta-analysis to be carried out. Despite this, being that this study is the first systematic review to summarize the evidence available on the seroprevalence and lethality of SARS-CoV-2 infection in the indigenous population of LAC, we consider that the use of a search strategy with exhaustive key terms allowed an adequate approach to the problem under study.

\section{CONCLUSIONS}

68 In conclusion, this systematic review found that there is limited evidence on the seroprevalence

371 COVID-19 is a cause of death in these LAC indigenous populations, although there were 372 differences in the lethality reported in hospital and community settings during the pandemic. In 


\section{REFERENCES}

379 1. World Health Organization. WHO Director-General's opening remarks at the media

380 briefing on COVID-19 - 11 March 2020 [Internet]. 2019. Available from:

$381 \mathrm{https} / / \mathrm{www}$. who.int/director-general/speeches/detail/who-director-general-s-opening-remarks-

382 at-the-media-briefing-on-covid-19---11-march-2020

383 2. Zhou B, Kojima S, Kawamoto A, Fukushima M. COVID-19 pathogenesis, prognostic

384 factors, and treatment strategy: Urgent recommendations. Journal of Medical Virology. 2021

385 May;93(5):2694-704.

386 3. McLeod M, Gurney J, Harris R, Cormack D, King P. COVID-19: we must not forget

387 about Indigenous health and equity. Aust N Z J Public Health [Internet]. 2020 Jul 6 [cited 2021

388 Jan 13]; Available from: https://www.ncbi.nlm.nih.gov/pmc/articles/PMC7361596/

389 4. Charlier P, Varison L. Is COVID-19 being used as a weapon against Indigenous Peoples

390 in Brazil? The Lancet. 2020 Oct 10;396(10257):1069-70.

3915 5. COVID-19 and Indigenous peoples | United Nations For Indigenous Peoples [Internet].

392 [cited 2021 Jan 18]. Available from:

393 https://www.un.org/development/desa/indigenouspeoples/covid-19.html

394 6. Gelaye B, Foster S, Bhasin M, Tawakol A, Fricchione G. SARS-CoV-2 morbidity and

395 mortality in racial/ethnic minority populations: A window into the stress related inflammatory

396 basis of health disparities? Brain Behav Immun - Health. 2020 Dec;9:100158.

397 7. La Ruche G, Tarantola A, Barboza P, Vaillant L, Gueguen J, Gastellu-Etchegorry M, et

398 al. The 2009 pandemic H1N1 influenza and indigenous populations of the Americas and the

399 Pacific. Euro Surveill Bull Eur Sur Mal Transm Eur Commun Dis Bull. 2009 Oct 22;14(42).

400 8. Food and Agriculture Organization. COVID-19 and indigenous peoples [Internet]. 2020.

401 Available from: http://www.fao.org/3/ca9106en/CA9106EN.pdf

402 9. Johns Hopkins University. Coronavirus Resource Center [Internet]. Available from:

403 https://coronavirus.jhu.edu/map.html

404 10. Rodriguez-Morales AJ, Gallego V, Escalera-Antezana JP, Méndez CA, Zambrano LI,

405 Franco-Paredes C, et al. COVID-19 in Latin America: The implications of the first confirmed

406 case in Brazil. Travel Med Infect Dis. 2020 Jun;35:101613.

407 11. United Nations Office for the Coordination of Humanitarian Affairs. Pueblos indígenas y

408 COVID-19 en América Latina [Internet]. 2020. Available from:

409 https://reliefweb.int/sites/reliefweb.int/files/resources/PUEBLOS\%20INDIGENAS\%20Y\%20C

410 OVID-19.pdf

411 12. Pan American Health Organization, World Health Organization. The Impact of COVID-

41219 on the Indigenous Peoples of the Region of the Americas: Perspectives and Opportunities.

413 Report on the High-Level Regional [Internet]. 2021. Available from:

414 https://iris.paho.org/bitstream/handle/10665.2/53428/PAHOEGCCOVID-

415 19210001_eng.pdf?sequence=1\&isAllowed=y

416 13. Stroup DF, Berlin JA, Morton SC, Olkin I, Williamson GD, Rennie D, et al. Meta-

417 analysis of Observational Studies in EpidemiologyA Proposal for Reporting. JAMA. 2000 Apr

418 19;283(15):2008-12.

419 14. PRISMA. PRISMA Statement [Internet]. 2015. Available from: http://www.prisma-

420 statement.org/PRISMAStatement/PRISMAStatement

421 15. Munn Z, Moola S, Lisy K, Riitano D, Tufanaru C. Methodological guidance for

422 systematic reviews of observational epidemiological studies reporting prevalence and cumulative

423 incidence data. JBI Evid Implement. 2015 Sep;13(3):147-53. 
424 16. Burki T. China's successful control of COVID-19. Lancet Infect Dis. 2020 Nov 425 1;20(11):1240-1.

426 17. Haddaway NR, Collins AM, Coughlin D, Kirk S. The Role of Google Scholar in 427 Evidence Reviews and Its Applicability to Grey Literature Searching. PLOS ONE. 2015 Sep 428 17;10(9):e0138237.

429 18. Bramer WM, Rethlefsen ML, Kleijnen J, Franco OH. Optimal database combinations for 430 literature searches in systematic reviews: a prospective exploratory study. Syst Rev. 2017 Dec $4316 ; 6(1): 245$.

432 19. NIH. National Heart, Lunga, and Blood Institute. Study Quality Assessment Tools 433 [Internet]. [cited 2021 Jan 17]. Available from: https://www.nhlbi.nih.gov/health-topics/study434 quality-assessment-tools

435 20. Ahmed S, Uddin R, Ziviani J, Khan A. Global Prevalence of Physical Activity, Sedentary 436 Behaviour, and Sleep of Immigrant Children: a Systematic Review. J Racial Ethn Health 437 Disparities. 2020 Oct 29;

438 21. Hinds N, Angioi M, Birn-Jeffery A, Twycross-Lewis R. A systematic review of shoulder 439 injury prevalence, proportion, rate, type, onset, severity, mechanism and risk factors in female 440 artistic gymnasts. Phys Ther Sport Off J Assoc Chart Physiother Sports Med. 2019 Jan;35:10644115.

442 22. Hallal PC, Hartwig FP, Horta BL, Silveira MF, Struchiner CJ, Vidaletti LP, et al. SARS443 CoV-2 antibody prevalence in Brazil: results from two successive nationwide serological 444 household surveys. Lancet Glob Health. 2020 Nov 1;8(11):e1390-8.

445 23. Baqui P, Bica I, Marra V, Ercole A, Schaar M van der. Ethnic and regional variations in 446 hospital mortality from COVID-19 in Brazil: a cross-sectional observational study. Lancet Glob 447 Health. 2020 Aug 1;8(8):e1018-26.

448 24. Santos VS, Souza Araújo AA, de Oliveira JR, Quintans-Júnior LJ, Martins-Filho PR. 449 COVID-19 mortality among Indigenous people in Brazil: a nationwide register-based study. J 450 Public Health. 2020 Oct 12;fdaa176.

451 25. Palamim CVC, Ortega MM, Marson FAL. COVID-19 in the Indigenous Population of 452 Brazil. J Racial Ethn Health Disparities. 2020 Dec 1;7(6):1053-8.

453 26. Horta B, Silveira M, Barros A, Barros F, Hartwig F, Dias M, et al. Prevalence of 454 antibodies against SARS-CoV-2 according to socioeconomic and ethnic status in a nationwide 455 Brazilian survey. Rev Panam Salud Pública. 2020;44:1-7.

456 27. Rodrigues EPS, Abreu IN, Lima CNC, da Fonseca DLM, Pereira SFG, Dos Reis LC, et 457 al. High prevalence of anti-SARS-CoV-2 IgG antibody in the Xikrin of Bacajá (Kayapó) 458 indigenous population in the brazilian Amazon. Int J Equity Health. 2021 Jan 28;20(1):50.

459 28. da Silva WNT da, Rosa MFP, Mendonça KS, Queiroz G de A, Oliveira SV de. Síndrome 460 respiratória aguda grave em indígenas no contexto da pandemia da COVID-19 no Brasil: uma 461 análise sob a perspectiva da vigilância epidemiológica. Vigilância Sanitária Em Debate Soc 462 Ciênc Tecnol Health Surveill Debate Soc Sci Technol - Visa Em Debate. 2021 Feb 26;9(1):246311.

464 29. Escobar AL, Rodriguez TDM, Monteiro JC. Letalidade e características dos óbitos por 465 COVID-19 em Rondônia: estudo observacional. Epidemiol E Serviços Saúde. 2020;30.

466 30. Mendes MF, Pereira LR, Lima TM, Melani VF, Palamim CVC, Boschiero MN, et al. 467 COVID-19 pandemic evolution in the Brazilian Indigenous population. J Racial Ethn Health 468 Disparities. 2021 Mar 29;1-17.

469 31. da Silva MG, Pereira PMB, Portela WF, Daros GC, Barbosa CR de A, Vanassi BM, et al. 
470 Epidemiology of COVID-19 Among Indigenous Populations in Brazil. J Racial Ethn Health

471 Disparities [Internet]. 2021 Apr 12 [cited 2021 Jul 9]; Available from:

472 https://doi.org/10.1007/s40615-021-01035-2

473 32. Hillesheim D, Tomasi YT, Figueiró TH, Paiva KM de. Síndrome respiratória aguda grave 474 por COVID-19 em crianças e adolescentes no Brasil: perfil dos óbitos e letalidade hospitalar até

475 a 38a Semana Epidemiológica de 2020. Epidemiol E Serviços Saúde. 2020;29.

476 33. Ortiz-Hernández L, Pérez-Sastré MA. Inequidades sociales en la progresión de la

477 COVID-19 en población mexicana. Rev Panam Salud Pública. 2020 Sep 25;44:1.

478 34. Argoty-Pantoja AD, Robles-Rivera K, Rivera-Paredez B, Salmerón J. COVID-19 fatality

479 in Mexico's indigenous populations. Public Health. 2021 Apr 1;193:69-75.

480 35. Ibarra-Nava I, Flores-Rodriguez KG, Ruiz-Herrera V, Ochoa-Bayona HC, Salinas-

481 Zertuche A, Padilla-Orozco M, et al. Ethnic disparities in COVID-19 mortality in Mexico: A

482 cross-sectional study based on national data. PLOS ONE. 2021 Mar 10;16(3):e0239168.

483 36. Cifuentes MP, Rodriguez-Villamizar LA, Rojas-Botero ML, Alvarez-Moreno CA, 484 Fernández-Niño JA. Socioeconomic inequalities associated with mortality for COVID-19 in 485 Colombia: a cohort nationwide study. J Epidemiol Community Health. 2021 Mar 4;jech-2020486216275.

487 37. Hatcher SM, Agnew-Brune C, Anderson M, Zambrano LD, Rose CE, Jim MA, et al. 488 COVID-19 Among American Indian and Alaska Native Persons - 23 States, January 31-July 3, 489 2020. Morb Mortal Wkly Rep. 2020 Aug 28;69(34):1166-9.

490 38. FILAC. Covid:19 CIDH reitera su preocupación por indígenas en Bolivia [Internet].

491 FILAC | Fondo para el Desarrollo de los Pueblos Indígenas de América Latina y El Caribe. 2020 492 [cited 2021 Jan 18]. Available from: https://www.filac.org/wp/comunicacion/actualidad493 indigena/covid19-cidh-reitera-su-preocupacion-por-indigenas-en-bolivia/

494 39. Centro Nacional de Epidemiología Prevención y Control de Enfermedades. Sala de 495 población indígena con COVID-19 [Internet]. [cited 2021 Jan 18]. Available from:

496 https://www.dge.gob.pe/portalnuevo/informacion-publica/sala-de-poblacion-indigena-con-covid-

$49719 /$

498 40. Castro LAT. El COVID-19 en las comunidades indígenas de Chimborazo, Ecuador. Lat 499 Am Caribb Ethn Stud. 2020 Oct 1;15(4):413-24.

500 41. Fondo para el Desarrollo de los Pueblos Indígenas de América Latina y el Caribe. Más de 501 mil indígenas en Colombia se han contagiado de Covid-19 [Internet]. FILAC | Fondo para el 502 Desarrollo de los Pueblos Indígenas de América Latina y El Caribe. 2020 [cited 2021 Jan 18]. 503 Available from: https://www.filac.org/wp/comunicacion/actualidad-indigena/mas-de-mil504 indigenas-en-colombia-se-han-contagiado-de-covid-19/

505 42. Reinders S, Alva A, Huicho L, Blas MM. Indigenous communities' responses to the 506 COVID-19 pandemic and consequences for maternal and neonatal health in remote Peruvian 507 Amazon: a qualitative study based on routine programme supervision. BMJ Open. 2020 Dec 508 1;10(12):e044197.

509 43. Fondo para el Desarrollo de los Pueblos Indígenas de América Latina y el Caribe. The 510 impact of COVID-19 on indigenous peoples in Latin America (Abya Yala). Between invisibility 511 and collective resistance [Internet]. 2020. Available from:

512 https://www.cepal.org/sites/default/files/publication/files/46698/S2000893_en.pdf

513 44. Fondo para el Desarrollo de los Pueblos Indígenas de América Latina y el Caribe. Covid 514 en la amazonia peruana: la lucha de los pueblos indígenas por sobrevivir [Internet]. 2021 [cited 5152021 Jan 18]. Available from: https://www.filac.org/covid-en-la-amazonia-peruana-la-lucha-de- 
516 los-pueblos-indigenas-por-sobrevivir/

517 45. Fondo para el Desarrollo de los Pueblos Indígenas de América Latina y el Caribe. Covid 518 en la amazonia peruana: la lucha de los pueblos indígenas por sobrevivir [Internet]. 2021 [cited

5192021 Jan 18]. Available from: https://www.filac.org/covid-en-la-amazonia-peruana-la-lucha-de520 los-pueblos-indigenas-por-sobrevivir

521 46. Pan American Health Organization. Protecting indigenous communities from COVID-19

522 [Internet]. Available from: paho.org/en/stories/protecting-indigenous-communities-covid-19

523 47. Álvares D. Top court rules Brazil must protect Indigenous in pandemic. Washington Post 524 [Internet]. [cited 2021 Jan 17]; Available from:

525 https://www.washingtonpost.com/world/the_americas/top-court-rules-brazil-must-protect526 indigenous-in-pandemic/2020/08/05/8698bdd0-d77a-11ea-a788-2ce86ce81129_story.html

527 48. Villén-Pérez S, Moutinho P, Nóbrega CC, De Marco P Jr. Brazilian Amazon gold:

528 indigenous land rights under risk. Allison S, editor. Elem Sci Anthr [Internet]. 2020 Jul 10 [cited 529 2021 Jan 17];8(31). Available from: https://doi.org/10.1525/elementa.427

530 49. Langlois J. Amazon gold mining drives malaria surges among Indigenous peoples.

531 National Geographic [Internet]. 2020 Aug 12 [cited 2021 Jan 17]; Available from:

$532 \mathrm{https} / /$ www.nationalgeographic.com/science/2020/08/gold-mining-deforestation-amazon-drives533 malaria-surges-brazil-indigenous-peoples/

534 50. Swenson JJ, Carter CE, Domec J-C, Delgado CI. Gold Mining in the Peruvian Amazon:

535 Global Prices, Deforestation, and Mercury Imports. PLOS ONE. 2011 Apr 19;6(4):e18875.

536 51. Meneses-Navarro S, Freyermuth-Enciso MG, Pelcastre-Villafuerte BE, Campos-Navarro

537 R, Meléndez-Navarro DM, Gómez-Flores-Ramos L. The challenges facing indigenous

538 communities in Latin America as they confront the COVID-19 pandemic. Int J Equity Health.

5392020 Dec;19(1):63.

540 
Figure 1

Flowchart of the selection of studies according to the PRISMA guidelines. 
Figure 1. Flowchart of the selection of studies according to the PRISMA guidelines.

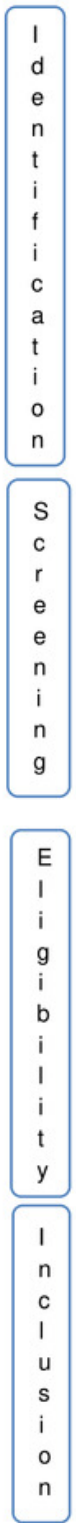

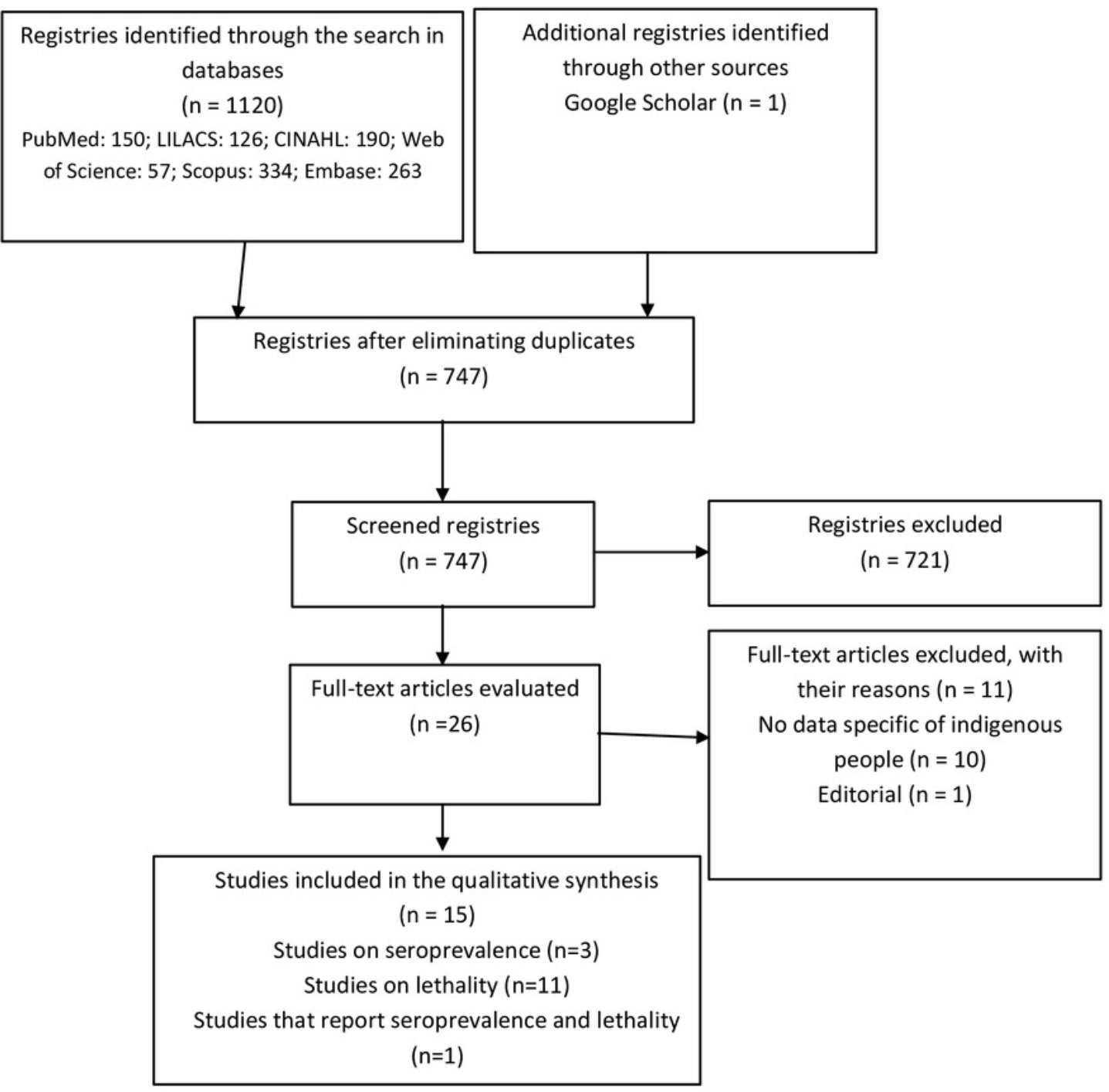




\section{Table $\mathbf{1}$ (on next page)}

Extraction of data on seroprevalence and lethality of SARS-CoV-2 among indigenous people from the studies selected.

ND: No Data; SIVEP-Gripe: Influenza Epidemiological Surveillance Information System;

SISVER: Epidemiological Surveillance System for Viral Respiratory Diseases; RT-PCR: Reverse transcriptase polymerase chain reaction; SIVIGILA: National Public Health Surveillance System; *Adjusted for the design and validity of the test. 
1 Table 1. Extraction of data on seroprevalence and lethality of SARS-CoV-2 among indigenous people from the studies selected.

\begin{tabular}{|c|c|c|c|c|c|c|c|c|c|c|c|c|c|}
\hline \multirow[b]{2}{*}{ Study } & \multirow[b]{2}{*}{ Country } & \multirow[b]{2}{*}{$\begin{array}{c}\text { Study } \\
\text { Design }\end{array}$} & \multirow[b]{2}{*}{ Data source } & \multicolumn{5}{|c|}{ Seroprevalence } & \multicolumn{5}{|c|}{ Lethality } \\
\hline & & & & Setting & Test & Sample & $\begin{array}{l}\text { Mean Age } \\
\text { (SD) /Sex } \\
(\%)\end{array}$ & \begin{tabular}{|l|}
$\begin{array}{l}\text { Prevalence (N } \\
\text { of individuals } \\
\text { with positive } \\
\text { antibody test// } \\
\text { sample) }\end{array}$ \\
\end{tabular} & Setting & Test & $\begin{array}{l}\text { COVID- } \\
19 \text { Cases }\end{array}$ & $\begin{array}{l}\text { Mean Age } \\
\text { (SD) /Sex (\%) }\end{array}$ & \begin{tabular}{|l|} 
Lethality (N \\
COVID-19 \\
patients dis \\
N of COVII \\
Cases) \\
\end{tabular} \\
\hline $\begin{array}{l}\text { 1) Baqui } \\
\text { et al., } \\
2020\end{array}$ & Brazil & \begin{tabular}{|l|} 
Cross \\
sectional
\end{tabular} & $\begin{array}{l}\text { SIVEP-Gripe } \\
\text { (public } \\
\text { dataset from } \\
\text { Feb } 27 \text { to } \\
\text { May 4, 2020) }\end{array}$ & ND & ND & ND & ND & ND & Hospital & RT-PCR & 15 & ND & $8 / 15=53.33^{\circ}$ \\
\hline $\begin{array}{l}\text { 2) Hallal } \\
\text { et al., } \\
2020\end{array}$ & Brazil & $\begin{array}{l}\text { Cross } \\
\text { sectional }\end{array}$ & $\begin{array}{l}\text { Household } \\
\text { survey } \\
\text { (conducted in } \\
2 \text { dates: May } \\
14-21, \\
\text { and June 4-7, } \\
2020, \text { ) }\end{array}$ & Community & $\begin{array}{l} \\
\text { WONDF } \\
\text { O SARS- } \\
\text { CoV-2 } \\
\text { Antibody } \\
\text { Test }\end{array}$ & $\begin{array}{l}\text { Survey } \\
1: 327 \\
\\
\\
\text { Survey } \\
2: 440\end{array}$ & ND & $\begin{array}{l}\text { Survey 1: } \\
12 / 327=4.2 \% * \\
95 \% \text { CI }(2.2-7.2) \\
\\
\text { Survey 2: } \\
24 / 440=6.3 \% * \\
95 \% \text { CI }(4.2-9.2)\end{array}$ & ND & ND & ND & ND & ND \\
\hline
\end{tabular}




\begin{tabular}{|c|c|c|c|c|c|c|c|c|c|c|c|c|c|}
\hline $\begin{array}{l}\text { 3) Ortiz- } \\
\text { Hernánde } \\
\text { z et al., } \\
2020\end{array}$ & Mexico & \begin{tabular}{|l|} 
Cross \\
sectional
\end{tabular} & \begin{tabular}{|l|} 
Data obtained \\
by the \\
Dirección \\
General de \\
Epidemiologí \\
a de la \\
Secretaria de \\
Salud del \\
Gobierno \\
Federal of \\
Mexico (data \\
up to July 10 \\
2020)
\end{tabular} & ND & ND & ND & ND & ND & Hospital & $\begin{array}{l}\text { Not } \\
\text { specified: } \\
\text { confirmed } \\
\text { and } \\
\text { suspicious } \\
\text { cases were } \\
\text { included }\end{array}$ & $\begin{array}{l}1 \% \text { (total } \\
\text { numbers } \\
\text { not } \\
\text { specified) }\end{array}$ & ND & $\begin{array}{l}19.9 \% \text { (total } \\
\text { numbers not } \\
\text { specified) }\end{array}$ \\
\hline $\begin{array}{l}\text { 4) } \\
\text { Palamim } \\
\text { et al., } \\
2020\end{array}$ & Brazil & \begin{tabular}{|l|} 
Cross \\
sectional
\end{tabular} & \begin{tabular}{|l|} 
Special \\
Secretariat \\
for \\
Indigenous \\
Health \\
(SESAI) \\
database (data \\
up to June 5 \\
2020)
\end{tabular} & ND & ND & ND & ND & ND & National & $\begin{array}{l}\text { Not } \\
\text { specified: } \\
\text { confirmed } \\
\text { and } \\
\text { suspicious } \\
\text { cases were } \\
\text { included }\end{array}$ & $\begin{array}{l}2157 \\
(\text { confirme } \\
\text { d cases }= \\
1737 ; \\
\text { suspected } \\
\text { cases }= \\
420)\end{array}$ & ND & $70 / 2157=3$ \\
\hline $\begin{array}{l}\text { 5) Santos } \\
\text { et al., } \\
2020\end{array}$ & Brazil & \begin{tabular}{|l|} 
Cross \\
sectional
\end{tabular} & \begin{tabular}{|l|} 
Microdata \\
catalog and \\
official \\
bulletins for \\
each Brazilian \\
state between \\
26 February \\
and 28 \\
August 2020
\end{tabular} & ND & ND & ND & ND & ND & $\begin{array}{l}\text { Commun } \\
\text { ity }\end{array}$ & $\begin{array}{l}\text { Not } \\
\text { specified: } \\
\text { confirmed } \\
\text { and } \\
\text { suspicious } \\
\text { cases were } \\
\text { included }\end{array}$ & 29,008 & ND & $532 / 29008=$ \\
\hline
\end{tabular}




\begin{tabular}{|c|c|c|c|c|c|c|c|c|c|c|c|c|c|}
\hline $\begin{array}{l}\text { 6) Horta } \\
\text { et al., } \\
2020\end{array}$ & Brazil & \begin{tabular}{|l|} 
Cross \\
sectional
\end{tabular} & \begin{tabular}{|l|} 
Household \\
survey \\
(conducted \\
from May 14- \\
21, June 4-7 \\
and June 21- \\
$24)$
\end{tabular} & Community & $\begin{array}{l}\text { WONDF } \\
\text { O SARS- } \\
\text { CoV-2 } \\
\text { Antibody } \\
\text { Test }\end{array}$ & 1219 & ND & $66 / 1219=5.4 \%$ & ND & ND & ND & ND & ND \\
\hline $\begin{array}{l}\text { 7) Argoty } \\
\text { et al., } \\
2021\end{array}$ & Mexico & $\begin{array}{l}\text { Longitu } \\
\text { dinal }\end{array}$ & \begin{tabular}{|l|} 
SISVER \\
\\
(February 27, \\
2020 until \\
July 30, 2020) \\
\end{tabular} & ND & ND & ND & ND & ND & National & $\begin{array}{l}\text { SARS- } \\
\text { CoV- } \\
2 \text { infection } \\
\text { certified by } \\
\text { the Institute } \\
\text { of } \\
\text { Epidemiolo } \\
\text { gical } \\
\text { Diagnosis } \\
\text { and } \\
\text { Reference } \\
\text { (InDRE) }\end{array}$ & 4469 & $\begin{array}{l}\text { Age } 50.4 \\
(17.4) \\
\\
\text { Male } 2656 \\
(59.4 \%)\end{array}$ & $768 / 4469=1$ \\
\hline $\begin{array}{l}8 \text { ) } \\
\text { Cifuentes } \\
\text { et al., } \\
2021\end{array}$ & $\begin{array}{l}\text { Colombi } \\
\mathrm{a}\end{array}$ & $\begin{array}{l}\text { Retrospe } \\
\text { ctive } \\
\text { cohort }\end{array}$ & $\begin{array}{l}\text { SIVIGILA (2 } \\
\text { March } 2020 \\
\text { to 26 October } \\
2020)\end{array}$ & ND & ND & ND & ND & ND & National & RT-PCR & 22,787 & ND & $\begin{array}{l}776 / 22787= \\
3.41 \%\end{array}$ \\
\hline $\begin{array}{l}\text { 9) } \mathrm{Da} \\
\text { Silva et } \\
\text { al., } 2021\end{array}$ & Brazil & $\begin{array}{l}\text { Cross } \\
\text { sectional }\end{array}$ & $\begin{array}{l}\text { SIVEP-Gripe } \\
\text { (January 1st } \\
\text { to June } 16 \\
2017,2018 \\
2019 \text { and } \\
2020 \text { ) }\end{array}$ & ND & ND & ND & ND & ND & National & ND & 318 & $\begin{array}{l}\text { Male } \\
195(61.32 \%)\end{array}$ & $155 / 318=48$ \\
\hline
\end{tabular}




\begin{tabular}{|c|c|c|c|c|c|c|c|c|c|c|c|c|c|}
\hline $\begin{array}{l}10) \\
\text { Escobar } \\
\text { et al., } \\
2021\end{array}$ & Brazil & \begin{tabular}{|l|} 
Cross \\
sectional
\end{tabular} & \begin{tabular}{|l|} 
Brazilian \\
National \\
Health \\
System \\
Epidemiologi \\
cal \\
Surveillance \\
System \\
Computerizati \\
on Strategy \\
(January 1 \\
and August \\
$20,2020)$
\end{tabular} & ND & ND & ND & ND & ND & National & ND & 843 & ND & $12 / 843=1.42$ \\
\hline $\begin{array}{l}\text { 11) } \\
\text { Hilleshei } \\
\text { m et al., } \\
2021\end{array}$ & Brazil & \begin{tabular}{|l|} 
Cross \\
sectional
\end{tabular} & \begin{tabular}{|l|} 
SIVEP-Gripe \\
(Epidemiologi \\
cal Weeks 1 \\
to 38,2020 \\
$($ up to \\
$19 / 09 / 2020)$ )
\end{tabular} & ND & ND & ND & ND & ND & $\begin{array}{l}\text { National } \\
\text { of } \\
\text { hospitali } \\
\text { zed } \\
\text { patients }\end{array}$ & $\begin{array}{l}\text { Laboratory } \\
\text { diagnosis - } \\
\text { not } \\
\text { specified }\end{array}$ & 113 & $\begin{array}{l}\text { Study included } \\
\text { children and } \\
\text { adolescents } \\
\text { (not specified) }\end{array}$ & $26 / 113=23 \%$ \\
\hline $\begin{array}{l}\text { 12) Ibarra } \\
\text { et al., } \\
2021\end{array}$ & Mexico & \begin{tabular}{|l|} 
Cross \\
sectional
\end{tabular} & $\begin{array}{l}\text { SISVER } \\
\text { (February 28 } \\
\text { to August 3, } \\
2020 \text { ) }\end{array}$ & ND & ND & ND & ND & ND & National & RT-PCR & 4178 & $\begin{array}{l}\begin{array}{l}\text { Non } \\
\text { survivors: }\end{array} \\
\text { Age: } 63.4 \\
(13.0) \\
\text { Male } 461 \\
(18.5 \%)\end{array}$ & $691 / 4178=1$ \\
\hline $\begin{array}{l}\text { 13) } \\
\text { Mendes et } \\
\text { al., } 2021\end{array}$ & Brazil & \begin{tabular}{|c|} 
Cross \\
sectional
\end{tabular} & $\begin{array}{l}\text { Press releases } \\
\text { by the Health } \\
\text { Ministry of } \\
\text { Brazil }\end{array}$ & ND & ND & ND & ND & ND & National & $\begin{array}{l}\text { Laboratory } \\
\text { analysis } \\
\text { (not } \\
\text { specified) } \\
\text { and by } \\
\text { clinical } \\
\text { criteria }\end{array}$ & 41,855 & ND & $549 / 41855=$ \\
\hline
\end{tabular}




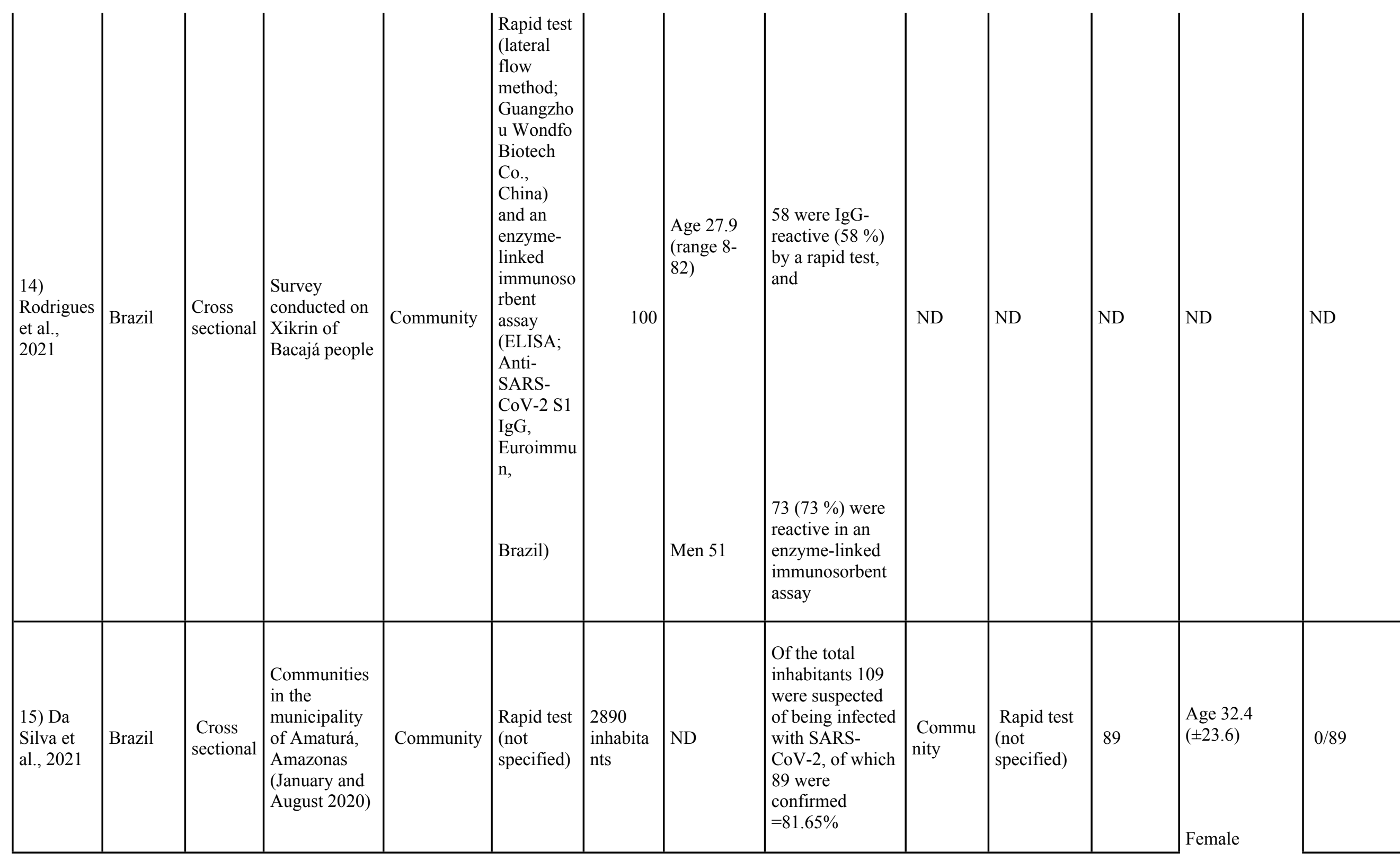




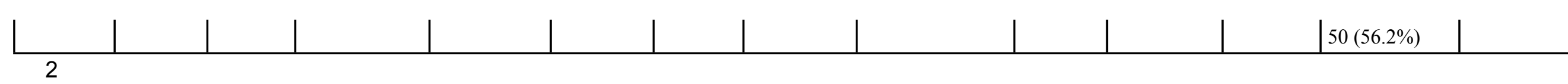

3 ND: No Data; SIVEP-Gripe: Influenza Epidemiological Surveillance Information System; SISVER: Epidemiological Surveillance

4 System for Viral Respiratory Diseases; RT-PCR: Reverse transcriptase polymerase chain reaction; SIVIGILA: National Public Health

5 Surveillance System; *Adjusted for the design and validity of the test.

6

7 


\section{Table 2 (on next page)}

Evaluation of the quality of the studies included $(n=15)$.

NA: Non-applicable; ND: not possible to determine. 
1 Table 2. Evaluation of the quality of the studies included $(n=15)$.

\begin{tabular}{|c|c|c|c|c|c|c|c|c|c|c|c|c|c|c|c|}
\hline Study & P1 & $\mathbf{P 2}$ & P3 & P4 & P5 & P6 & P7 & P8 & P9 & P10 & P11 & P12 & P13 & P14 & Rating \\
\hline Baqui et al. 2020 & Yes & Yes & Yes & Yes & No & No & No & NA & Yes & NA & Yes & NA & NA & Yes & $70.0 \%$ \\
\hline Halla et al. 2020 & Yes & Yes & Yes & Yes & No & No & No & NA & Yes & NA & Yes & No & NA & Yes & $63.6 \%$ \\
\hline Ortiz-Hernandez et al. 2020 & Yes & Yes & Yes & Yes & No & No & No & NA & Yes & NA & No & NA & NA & Yes & $60.0 \%$ \\
\hline Palamim et al. 2020 & Yes & Yes & Yes & Yes & No & No & No & NA & Yes & NA & No & NA & NA & NA & $62.5 \%$ \\
\hline Santos et al. 2020 & Yes & Yes & Yes & No & NA & No & No & NA & NA & NA & No & NA & NA & NA & $50.0 \%$ \\
\hline Horta et al. 2020 & Yes & Yes & Yes & Yes & Yes & No & No & NA & Yes & NA & Yes & No & NA & Yes & $72.7 \%$ \\
\hline Argoty et al., 2021 & Yes & Yes & Yes & Yes & No & No & No & NA & Yes & NA & Yes & NA & NA & Yes & $70.0 \%$ \\
\hline Cifuentes et al., 2021 & Yes & Yes & Yes & Yes & No & No & No & NA & Yes & NA & Yes & NA & NA & No & $60.0 \%$ \\
\hline Da Silva et al., 2021 & Yes & Yes & Yes & Yes & No & No & No & NA & Yes & NA & Yes & NA & NA & NA & $66.7 \%$ \\
\hline Escobar et al., 2021 & Yes & Yes & Yes & Yes & No & No & No & NA & Yes & NA & Yes & NA & NA & No & $60.0 \%$ \\
\hline Hellesheim et al., 2021 & Yes & Yes & Yes & Yes & No & No & No & NA & Yes & NA & Yes & NA & NA & No & $60.0 \%$ \\
\hline Ibarra et al., 2021 & Yes & Yes & Yes & Yes & No & No & No & NA & Yes & NA & Yes & NA & NA & Yes & $70.0 \%$ \\
\hline Mendes et al., 2021 & Yes & Yes & Yes & No & NA & No & ND & NA & NA & NA & Yes & NA & NA & NA & $57.1 \%$ \\
\hline Rodrigues et al., 2021 & Yes & Yes & ND & Yes & No & No & No & NA & Yes & NA & Yes & No & NA & NA & $50.0 \%$ \\
\hline Da Silva et al., 2021 & Yes & Yes & No & Yes & No & No & No & NA & Yes & NA & Yes & No & NA & NA & $50.0 \%$ \\
\hline
\end{tabular}

2 NA: Non-applicable; ND: not possible to determine 